\title{
Effect of Cutting Parameters on Cutting Force and Surface Roughness of Aluminium Components using Face Milling Process - a Taguchi Approach
}

\author{
Anil Antony Sequeira', Ravikantha Prabhu², N.S.Sriram³, \\ Thirumaleshwara Bhat ${ }^{4}$ \\ ${ }^{1}$ Corresponding Author \\ ${ }^{1,2,4}$ Department of Mechanical Engineering, St. Joseph Engineering College, Mangalore - 575028 Karnataka \\ INDIA. \\ ${ }^{3}$ Department of Mechanical Engineering, Vidya Vikas Institute of Engineering and Technology \\ Mysore - 570010 Karnataka INDIA.
}

\begin{abstract}
Aluminum is used excessively in the modern world and the uses of the metals are extremely diverse due to its many unusual combinations of properties. They have been widely used in industries, especially aerospace industries due to their attractive mechanical and chemical properties. However, machining of Aluminium results in good surface finish at the expense of tooling cost. This study investigates the optimum parameters that could produce significant good surface finish and optimum cutting force thereby reducing tooling cost. It employs the Taguchi design method to optimize the surface roughness quality and cutting force in a Computer Numerical Control (CNC). The milling parameters evaluated are cutting speed, feed rate and depth of cut. An $L_{9}\left(3^{4}\right)$ orthogonal array, signal-to-noise $(S / N)$ ratio and analysis of variance (ANOVA) are employed to analyze the effect of these cutting parameters. The analysis of the result indicates that the optimal combination for low resultant cutting force and good surface finish are high cutting speed, low feed rate and low depth of cut. The study shows that the Taguchi method is suitable to solve the machining problems with minimum number of trials as compared with a full factorial design.
\end{abstract}

\section{INTRODUCTION}

Robust design is an engineering methodology for obtaining product and process conditions, which are minimally sensitive to the various causes of variation to produce high-quality products with low development and manufacturing costs [1]. Taguchi's parameter design is an important tool for robust design. It offers a simple and systematic approach to optimize design for performance, quality and cost. Two major tools used in robust design or Taguchi design are [1-6]:

- Signal to noise ratio, which measures quality with emphasis on variation, and

- Orthogonal arrays, which accommodate many design factors simultaneously.

When a critical quality characteristic deviates from the target value, it causes a loss [2]. Continuously pursuing variability reduction from the target value in critical quality characteristics is the key to achieve high quality and reduce cost.

The successful applications of Taguchi methods by both engineers and statisticians within British industry have lead to the formation of UK Taguchi Club [4]. Taguchi's approach is totally based on statistical design of experiments [1], and this can economically satisfy the needs of problem solving and product/process design optimization [5]. By applying this technique one can significantly reduce the time required for experimental investigation, as it is effective in investigating the effects of multiple factors on performance as well as to study the influence of individual factors to determine which factor has more influence, which less $[1,6]$. Some of the previous works that used the Taguchi method as tool for design of experiment in various areas including metal cutting are listed in Refs. [7-10].

Numerous roughness height parameters such as average roughness, smoothening depth, root mean square and maximum peak-to-valley height can be closely correlated. This study uses average roughness for the characterization of surface roughness, due to the fact that it is widely adopted in the industry for specifying the surface roughness. Mital M. Mehta [13] has conducted a survey of the previously developed surface roughness prediction models and factors influencing the surface roughness. He has found that most of the surface roughness prediction models have been developed for steels.

This paper describes a case study on face milling parameters at three levels each. The main objective is to find a combination of milling parameters to achieve low cutting force and surface roughness. 


\section{A Material}

\section{MATERIAL AND METHODS}

Aluminum is a soft, lightweight, malleable metal with appearance of a silver-white metal obtained from bauxite. The appearance may range from silvery to dull gray, depending on the surface roughness. The yield strength of pure aluminum is 7-11 MPa, while aluminum alloys have yield strengths ranging from 200 MPa to $600 \mathrm{MPa}$. Aluminum has about one-third the density and stiffness of steel. It is ductile, and can be easily machined, cast, and extruded. Aluminum is a good thermal and electrical conductor, by weight better than copper. Aluminum is capable of being a superconductor, with a superconducting critical temperature of 1.2 Kelvin and a critical magnetic field of about 100 gauss.

\section{$B$ Design of experiment}

Design of experiment is the powerful analysis tool for modeling and analyzing the influence of the control factors on the performance output. The most important stage in the design of experiment lies in the selection of the control factors. The operating conditions, under which measurement of cutting force carried out, are given in Table 1

The Taguchi method, which is effective to deal with responses, is influenced by multi-variables 16]. This method drastically reduces the number of experiments that are required to model the response function compared with the full factorial design of experiments. The Taguchi technique is devised for process optimization and identification of optimal combination of the factors for a given response. This technique is divided into three main phases, which encompasses all experimentation approaches. The three phases are (1) the planning phase (2) the conducting phase and (3) the analysis phase. This technique creates a standard orthogonal array to accommodate the effect of several factors on the target value and defines the plan of experiments. The experimental results are analyzed using analysis of means and variance to study the influence of factors.

Three parameters, viz., Feed Rate, Spindle Speed and Depth of Cut each at three levels, are considered in this study in accordance with $\mathrm{L}_{9}\left(3^{4}\right)$ orthogonal array design. The plan of the experiment is as follows: the first column is assigned to the Feed Rate (A), the second column to the Spindle Speed (B), the fourth column to the Depth of Cut (C).

TABLE I

Control factors and their levels

\begin{tabular}{cccc}
\hline Parameters & Level 1 & Level 2 & Level \\
\hline Feed Rate(mm/min) & 400 & 800 & 1600 \\
Spindle Speed(rpm) & 1300 & 1800 & 2600 \\
Depth of cut(mm) & 0.7 & 1.2 & 1.7 \\
\hline
\end{tabular}

The experimental observations are transformed into signal-to-noise $(\mathrm{S} / \mathrm{N})$ ratio. There are several $\mathrm{S} / \mathrm{N}$ ratios available depending on the type of characteristic, which can be calculated as logarithmic transformation of the loss function. For lower is the better characteristic, the following equation is used.

$\frac{\mathrm{s}}{\mathrm{N}}=-10 \log \frac{1}{\mathrm{n}}\left(\sum \mathrm{y}^{2}\right)$

Where ' $n$ ' is the number of observations, and ' $y$ ' the observed data. "Lower is the better" (LB) characteristic, with the above $\mathrm{S} / \mathrm{N}$ ratio transformation, is suitable for minimization of average cutting force measured along $\mathrm{X}, \mathrm{Y}$ and $\mathrm{Z}$ axes.

\section{Surface roughness evaluation}

There are various simple surface roughness amplitude parameters used in industry, such as roughness average (Ra), root-meansquare (rms) roughness $(\mathrm{Rq})$, and maximum peak-to-valley roughness (Ry or Rmax), etc. Since Ra and Rq are the most widely used surface parameters in industry, Ra was selected to express the surface roughness in this study. The average roughness ( $\mathrm{Ra}$ ) is the area between the roughness profile and its mean line, or the integral of the absolute value of the roughness profile height over the evaluation length (Fig.1). The $\mathrm{Ra}$ is specified by the following equation:

$$
R a=\frac{1}{L} \int_{0}^{L}|Y(x)| d x(\mu \mathrm{m})
$$




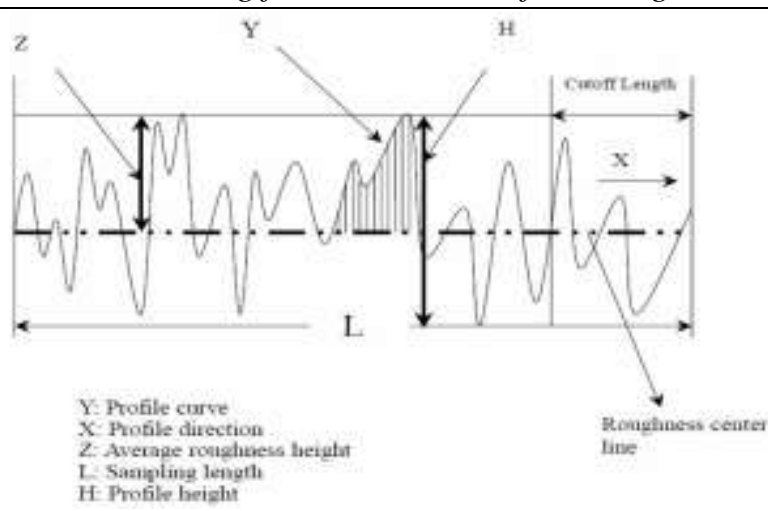

Fig.1. Surface roughness profile (Chen and Yang, 2001).

\section{A Machining parameter}

To improve the quality of surface roughness of Aluminium alloys and processes with minimum cost and time constraints, the Taguchi parameter design techniques are applied in design of experiment (DOE). Minimum surface roughness average ( $\mathrm{Ra}$ ) is carried out since the value represents better or improved surface roughness. Therefore, a smaller-the-better method is implemented in this experiment [14]. The controllable parameters are selected because of their potential effects on surface roughness performance in face milling operations. The parameters feed rate (A), cutting speed (B) and the depth of cut (C) used as control parameters to measure responses for surface roughness and signal-to-noise ratio can be calculated to determine the optimum cutting condition [15].

\section{$B$ Experimental Setup}

BFW Agni BMV 45 T20 CNC vertical axis milling machine is used for the machining of the Aluminium components. The milling cutter used for experimentation is SECO R220.69-12 grade. The tool holder used for experimentation was BT 40 grade. Face Milled components are shown in Figure 2. A Mitutoyo Surf test SJ-301 Profilometer was used to measure surface roughness (Ra) of the machined components. Variation in the cutting force during the machining is calculated using the spindle power. The average cutting force measured along $\mathrm{X}, \mathrm{Y}$ and $\mathrm{Z}$ axes called the Fx,Fy and Fz respectively.

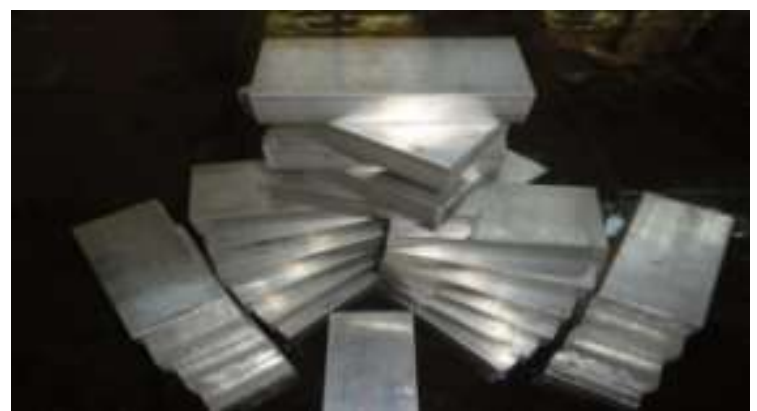

Fig.2. Face milled Aluminium work pieces.

\section{RESULTS AND DISCUSSIONS}

\section{- Analysis of Experimental Results}

The experimental data for cutting force and roughness is reported in the Table 2. From Table 2 the overall mean for the $\mathrm{S} / \mathrm{N}$ ratio of the cutting force $\mathrm{Fx}, \mathrm{Fy}, \mathrm{Fz}$ and the roughness are found to be $-54.32 \mathrm{db},-51.59$ $\mathrm{db}$ and $8.34 \mathrm{db}$ respectively. The analyses of the experimental data are carried using the software MINITAB 15 specially used for design of experiment applications.

\section{- Analysis of S/N Ratio}

Figs. 3-5 showed the main effects plot for $\mathrm{S} / \mathrm{N}$ ratios. The level of a factor with the highest $\mathrm{S} / \mathrm{N}$ ratio was the optimum level for responses measured. From the S/N ratio analysis in Figs. 1-3, the optimal machining conditions were $400 \mathrm{~mm} / \mathrm{min}$ feed rate (level 1), $2600 \mathrm{rpm}$ spindle speed (level 3) and $0.7 \mathrm{~mm}$ depth of cut (level 1) for cutting force $\mathrm{F}_{\mathrm{x}}, \mathrm{F}_{\mathrm{y}}$ and $\mathrm{F}_{\mathrm{z}}$. 


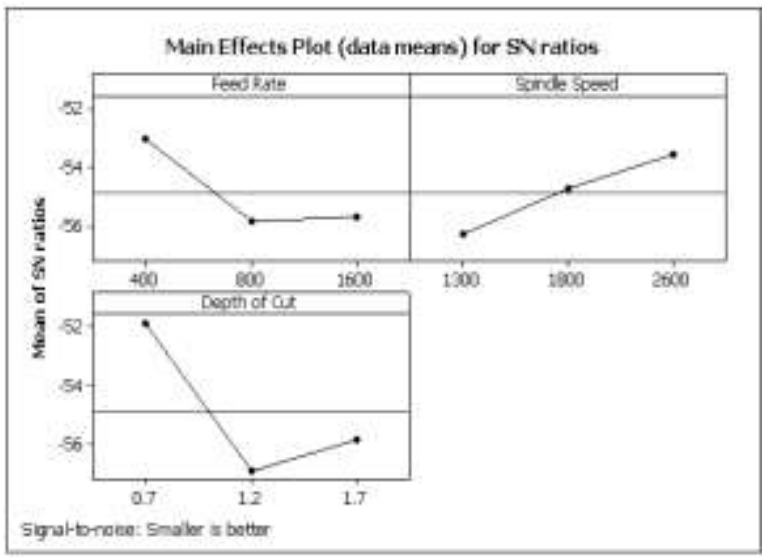

Fig.3. $\mathrm{S} / \mathrm{N}$ ratio values for $\mathrm{F}_{\mathrm{x}}$

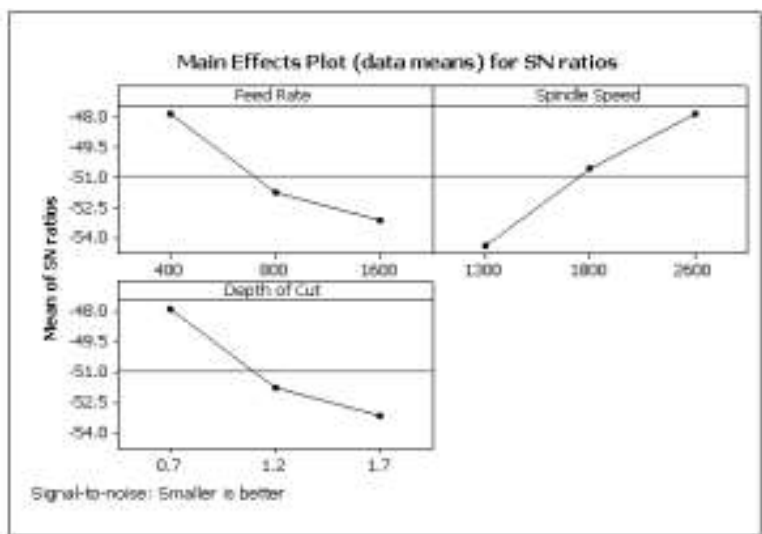

Fig.4. $S / \mathrm{N}$ ratio values for $\mathrm{F}_{\mathrm{y}}$

TABLE II

EXPERIMENTAL RESULTS

\begin{tabular}{ccccccccccc}
\hline $\begin{array}{c}\text { Feed } \\
\text { Rate } \\
(\mathrm{A})\end{array}$ & $\begin{array}{c}\text { Spindle } \\
\text { Speed } \\
(\mathrm{B})\end{array}$ & $\begin{array}{c}\text { Depth of } \\
\text { Cut }(\mathrm{C})\end{array}$ & $\mathrm{F}_{\mathrm{X}}(\mathrm{N})$ & $\mathrm{S} / \mathrm{N}$ Ratio & $\mathrm{F}_{\mathrm{Y}}(\mathrm{N})$ & $\mathrm{S} / \mathrm{N}$ Ratio & $\mathrm{F}_{\mathrm{Z}(\mathrm{N})}$ & $\mathrm{S} / \mathrm{N}$ Ratio & $\mathrm{R}_{\mathrm{a}}(\mu \mathrm{m})$ & $\begin{array}{c}\mathrm{S} / \mathrm{N} \\
\text { Ratio }\end{array}$ \\
\hline 400 & 1300 & 0.7 & 392 & -51.8657 & 235.2 & -47.4287 & 490 & -53.8039 & 0.18 & 14.8945 \\
400 & 1800 & 1.2 & 588 & -55.3875 & 274.4 & -48.7677 & 490 & -53.8039 & 0.11 & 19.1721 \\
400 & 2600 & 1.7 & 392 & -51.8657 & 235.2 & -47.4287 & 490 & -53.8039 & 0.39 & 8.1787 \\
800 & 1300 & 1.7 & 862.4 & -58.7142 & 784 & -57.8863 & 637 & -56.0828 & 0.48 & 6.3752 \\
800 & 1800 & 0.7 & 392 & -51.8657 & 274.4 & -48.7677 & 490 & -53.8039 & 0.23 & 12.7654 \\
800 & 2600 & 1.2 & 705.6 & -56.9712 & 274.4 & -48.7677 & 588 & -55.3875 & 0.3 & 10.4576 \\
1600 & 1300 & 1.2 & 823.2 & -58.3101 & 784 & -57.8863 & 637 & -56.0828 & 0.55 & 5.1927 \\
1600 & 1800 & 1.7 & 705.6 & -56.9712 & 509.6 & -54.1446 & 686 & -56.7265 & 0.31 & 10.1728 \\
1600 & 2600 & 0.7 & 392 & -51.8657 & 235.2 & -47.4287 & 539 & -54.6318 & 0.44 & 7.1309 \\
\hline
\end{tabular}




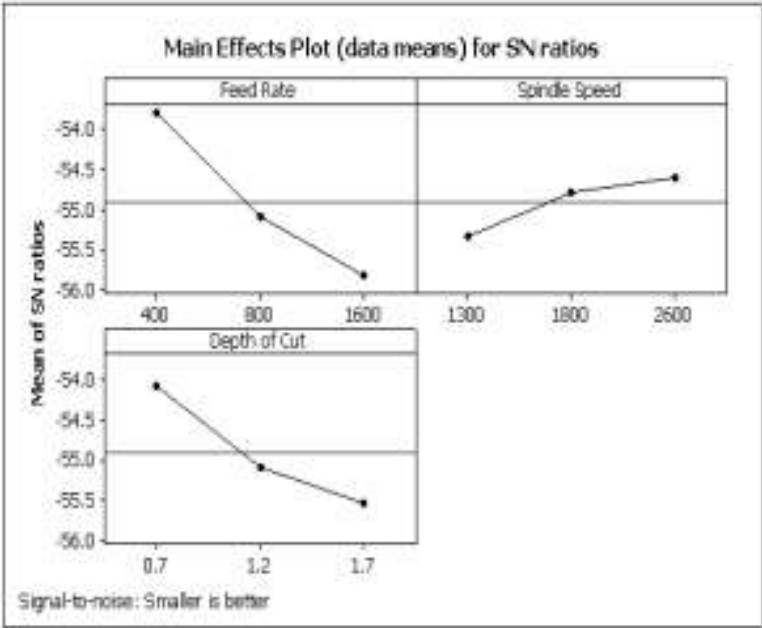

Fig.5. $\mathrm{S} / \mathrm{N}$ ratio values for $\mathrm{F}_{\mathrm{z}}$

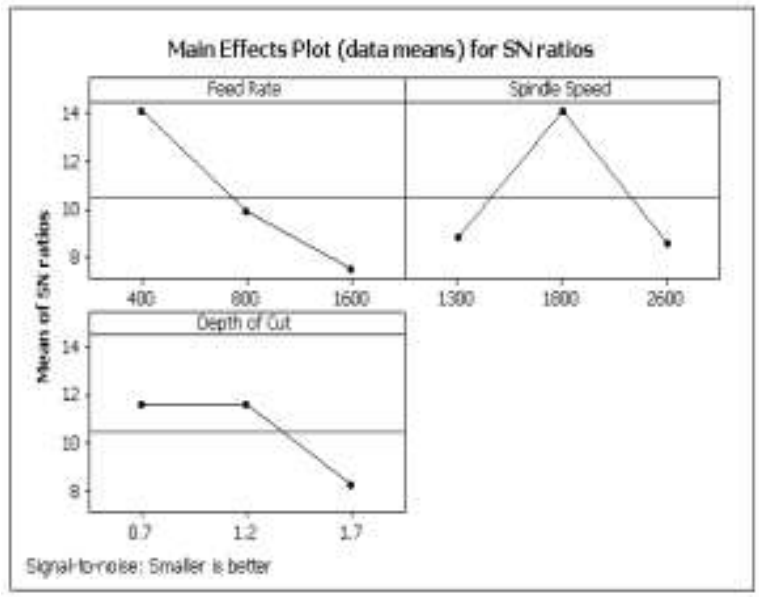

Fig.6. S/N ratio values for Surface Roughness

From Fig.6, the optimal machining conditions were $400 \mathrm{~m} / \mathrm{min}$ feed rate (level 1), $1800 \mathrm{rpm}$ spindle speed (level 2) and $0.7 \mathrm{~mm}$ depth of cut (level 1) respectively for surface roughness.

\section{- Analysis of Variance (ANOVA)}

ANOVA was used to determine the significant parameters influencing the surface roughness and force components in the milling of Aluminium specimen. Tables 3-6 showed the summary of S/N values and ANOVA results for cutting force $\mathrm{F}_{\mathrm{x}}, \mathrm{F}_{\mathrm{y}}, \mathrm{F}_{\mathrm{z}}$ and surface roughness, respectively. In this study, analysis was at a level of significance 5\%. In order to understand a concrete visualization of impact of various factors effect on the output performance, it is desirable to develop analysis of variance (ANOVA) table to find out the order of significant factors. From Table 3 one can observe that the depth of cut $(\mathrm{p}=0.072)$ has greater static influence of $58.76 \%$ followed by feed rate $(\mathrm{p}=0.179)$ has an influence of $20.99 \%$ and spindle speed $(\mathrm{p}=0.226)$ has an influence of $15.65 \%$ on cutting force $\mathrm{F}_{\mathrm{x}}$.

From Table 4 one can observe that the spindle speed $(\mathrm{p}=0.046)$ has greater static influence of $40.87 \%$ followed by feed rate and depth of cut ( $\mathrm{p}=0.064)$ has an influence of $28.58 \%$ on cutting force $\mathrm{F}_{\mathrm{y}}$.

From Table 5 one can observe that the feed rate $(\mathrm{p}=0.120)$ has greater static influence of $55.27 \%$ followed by depth of cut $(\mathrm{p}=0.202)$ has an influence of $29.76 \%$ and spindle speed $(\mathrm{p}=0.502)$ has an influence of $7.45 \%$ on cutting force $\mathrm{F}_{\mathrm{z}}$. 
Effect of cutting parameters on cutting force and the surface roughness of Aluminium components

TABLE III

SUMMARY OF S/N VALUES AND ANOVA RESULTS FOR FX

\begin{tabular}{|c|c|c|c|c|c|c|c|c|c|}
\hline \multirow[b]{2}{*}{ Factors } & \multirow{2}{*}{$\begin{array}{l}\text { Degrees } \\
\text { of } \\
\text { Freedom } \\
\text { DF } \\
\end{array}$} & \multicolumn{3}{|c|}{ Average S/N Values } & \multirow{2}{*}{$\begin{array}{l}\text { Sum of } \\
\text { Square }\end{array}$} & \multirow{2}{*}{$\begin{array}{c}\text { Mean } \\
\text { Square }\end{array}$} & \multirow[b]{2}{*}{$\mathbf{F}$} & \multirow[b]{2}{*}{$\mathbf{P}$} & \multirow{2}{*}{$\begin{array}{c}\text { Percentage } \\
\text { of } \\
\text { Contribution } \\
(\%)\end{array}$} \\
\hline & & $\begin{array}{c}\text { Level } \\
1\end{array}$ & $\begin{array}{c}\text { Level } \\
2\end{array}$ & $\begin{array}{c}\text { Level } \\
\mathbf{3}\end{array}$ & & & & & \\
\hline $\begin{array}{l}\text { Feed } \\
\text { Rate }\end{array}$ & 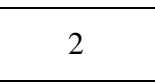 & -53.04 & -55.85 & -55.72 & 15.079 & 7.540 & 4.58 & 0.179 & 20.99 \\
\hline $\begin{array}{l}\text { Spindle } \\
\text { Speed }\end{array}$ & 2 & -56.30 & -54.74 & -53.57 & 11.245 & 5.622 & 3.42 & 0.226 & 15.65 \\
\hline $\begin{array}{l}\text { Depth of } \\
\text { Cut }\end{array}$ & 2 & -51.87 & -56.89 & -55.85 & 42.197 & 21.098 & 12.82 & 0.072 & 58.76 \\
\hline Error & 2 & & & & 3.292 & 1.646 & & & 4.60 \\
\hline Total & 8 & & & & 71.812 & & & & 100 \\
\hline
\end{tabular}

$\mathrm{S}=1.28289 \mathrm{R}-\mathrm{Sq}=95.42 \% \quad \mathrm{R}-\mathrm{Sq}(\mathrm{adj})=81.67 \%$

TABLE IV

SUMMARY OF S/N VALUES AND ANOVA RESULTS FOR FY

\begin{tabular}{|c|c|c|c|c|c|c|c|c|c|}
\hline \multirow[b]{2}{*}{ Factors } & \multirow{2}{*}{$\begin{array}{l}\text { Degrees } \\
\text { of } \\
\text { Freedom } \\
\text { DF }\end{array}$} & \multicolumn{3}{|c|}{ Average $\mathbf{S} / \mathbf{N}$ Values } & \multirow{2}{*}{$\begin{array}{l}\text { Sum of } \\
\text { Square }\end{array}$} & \multirow{2}{*}{$\begin{array}{c}\text { Mean } \\
\text { Square }\end{array}$} & \multirow[b]{2}{*}{$\mathbf{F}$} & \multirow[b]{2}{*}{$\mathbf{P}$} & \multirow{2}{*}{$\begin{array}{c}\text { Percentage } \\
\text { of } \\
\text { Contributio } \\
\text { n }(\%)\end{array}$} \\
\hline & & $\begin{array}{c}\text { Level } \\
1\end{array}$ & $\begin{array}{c}\text { Level } \\
2\end{array}$ & $\begin{array}{c}\text { Level } \\
\mathbf{3}\end{array}$ & & & & & \\
\hline $\begin{array}{l}\text { Feed } \\
\text { Rate }\end{array}$ & 2 & -47.88 & -51.81 & -53.15 & 45.133 & 22.566 & 14.51 & 0.064 & 28.58 \\
\hline $\begin{array}{c}\text { Spindle } \\
\text { Speed }\end{array}$ & 2 & -54.40 & -50.56 & -47.88 & 64.539 & 32.270 & 20.74 & 0.046 & 40.87 \\
\hline $\begin{array}{l}\text { Depth of } \\
\text { Cut }\end{array}$ & 2 & -47.88 & -51.81 & -53.15 & 45.133 & 22.566 & 14.51 & 0.064 & 28.58 \\
\hline Error & 2 & & & & 3.111 & 1.556 & & & 1.97 \\
\hline Total & 8 & & & & 157.916 & & & & 100 \\
\hline
\end{tabular}

$\mathrm{S}=1.24724 \quad \mathrm{R}-\mathrm{Sq}=98.03 \% \quad \mathrm{R}-\mathrm{Sq}(\mathrm{adj})=92.12 \%$

TABLE V

SUMMARY OF S/N VALUES AND ANOVA RESULTS FOR FZ

\begin{tabular}{|c|c|c|c|c|c|c|c|c|c|}
\hline \multirow[b]{2}{*}{ Factors } & \multirow{2}{*}{$\begin{array}{l}\text { Degrees } \\
\text { of } \\
\text { Freedom } \\
\text { DF }\end{array}$} & \multicolumn{3}{|c|}{ Average S/N Values } & \multirow{2}{*}{$\begin{array}{l}\text { Sum of } \\
\text { Square }\end{array}$} & \multirow{2}{*}{$\begin{array}{c}\text { Mean } \\
\text { Square }\end{array}$} & \multirow[b]{2}{*}{$\mathbf{F}$} & \multirow[b]{2}{*}{$\mathbf{P}$} & \multirow{2}{*}{$\begin{array}{c}\text { Percentage } \\
\text { of } \\
\text { Contribution } \\
(\%)\end{array}$} \\
\hline & & $\begin{array}{c}\text { Level } \\
1\end{array}$ & $\begin{array}{c}\text { Level } \\
2\end{array}$ & $\begin{array}{c}\text { Level } \\
\mathbf{3}\end{array}$ & & & & & \\
\hline $\begin{array}{c}\text { Feed } \\
\text { Rate }\end{array}$ & 2 & -53.80 & -55.09 & -55.81 & 6.2185 & 3.1092 & 7.36 & 0.120 & 55.27 \\
\hline $\begin{array}{l}\text { Spindle } \\
\text { Speed }\end{array}$ & 2 & -55.32 & -54.78 & -54.61 & 0.8379 & 0.4190 & 0.99 & 0.502 & 7.45 \\
\hline $\begin{array}{l}\text { Depth } \\
\text { of Cut }\end{array}$ & 2 & -54.08 & -55.09 & -55.54 & 3.3478 & 1.6739 & 3.96 & 0.202 & 29.76 \\
\hline Error & 2 & & & & 0.8450 & 0.4225 & & & 7.52 \\
\hline Total & 8 & & & & 11.2491 & & & & 100 \\
\hline
\end{tabular}

$\mathrm{S}=0.649991 \quad \mathrm{R}-\mathrm{Sq}=92.49 \% \quad \mathrm{R}-\mathrm{Sq}(\operatorname{adj})=69.95 \%$

From Table 6, one can observe that, the feed rate $(\mathrm{p}=0.188)$ has greater static influence of $41.26 \%$ followed by spindle speed $(\mathrm{p}=0.213)$ has an influence of $35.21 \%$ and depth of cut $(\mathrm{p}=0.406)$ has an influence of $13.96 \%$ on surface roughness. 
Effect of cutting parameters on cutting force and the surface roughness of Aluminium components

\section{TABLE VI}

SUMMARY OF S/N VALUES AND ANOVA RESULTS FOR ROUGHNESS

\begin{tabular}{|c|c|c|c|c|c|c|c|c|c|}
\hline \multirow[b]{2}{*}{ Factors } & \multirow{2}{*}{$\begin{array}{c}\text { Degrees } \\
\text { of } \\
\text { Freedom } \\
\text { DF }\end{array}$} & \multicolumn{3}{|c|}{ Average S/N Values } & \multirow{2}{*}{$\begin{array}{l}\text { Sum of } \\
\text { Square }\end{array}$} & \multirow{2}{*}{$\begin{array}{l}\text { Mean } \\
\text { Square }\end{array}$} & \multirow[b]{2}{*}{$\mathbf{F}$} & \multirow[b]{2}{*}{$\mathbf{P}$} & \multirow{2}{*}{$\begin{array}{c}\text { Percentage } \\
\text { of } \\
\text { Contribution } \\
(\%)\end{array}$} \\
\hline & & $\begin{array}{c}\text { Level } \\
1\end{array}$ & $\begin{array}{c}\text { Level } \\
2\end{array}$ & $\begin{array}{c}\text { Level } \\
\mathbf{3}\end{array}$ & & & & & \\
\hline Feed Rate & 2 & 14.082 & 9.866 & 7.499 & 66.712 & 33.356 & 4.32 & 0.188 & 41.26 \\
\hline $\begin{array}{c}\text { Spindle } \\
\text { Speed }\end{array}$ & 2 & 8.821 & 14.037 & 8.589 & 56.937 & 28.469 & 3.69 & 0.213 & 35.21 \\
\hline $\begin{array}{c}\text { Depth of } \\
\text { Cut }\end{array}$ & 2 & 11.597 & 11.607 & 8.242 & 22.580 & 11.290 & 1.46 & 0.406 & 13.96 \\
\hline Error & 2 & & & & 15.447 & 7.724 & & & 9.57 \\
\hline Total & 8 & & & & 161.677 & & & & 100 \\
\hline
\end{tabular}

$\mathrm{S}=2.77916 \quad \mathrm{R}-\mathrm{Sq}=90.45 \% \quad \mathrm{R}-\mathrm{Sq}(\operatorname{adj})=61.78 \%$

\section{CONCLUSION}

This study discussed the application of Taguchi experimental method for investigating the influence of milling parameters on cutting force and surface roughness during milling of Aluminum. In the milling experiments, different cutting speed, feed rate and depth of cut were utilized. The level of importance of the machining parameters on the cutting force and surface roughness was determined by ANOVA. Based on this study, the following conclusions can be drawn for the milling conditions:

1. The optimal machining conditions were $400 \mathrm{~mm} / \mathrm{min}$ feed rate (level 1), $2600 \mathrm{rpm}$ spindle speed (level 3) and $0.7 \mathrm{~mm}$ depth of cut (level 1) for cutting force $\mathrm{F}_{\mathrm{x}}$, Fy and $\mathrm{F}_{\mathrm{z}}$.

2. The optimal machining conditions were $400 \mathrm{~m} / \mathrm{min}$ feed rate (level 1), $1800 \mathrm{rpm}$ spindle speed (level 2) and $0.7 \mathrm{~mm}$ depth of cut (level 1) for surface roughness.

3. The depth of cut had a greater static influence followed by feed rate and spindle speed on cutting force component $F_{x}$.

4. The spindle speed had greater static influence followed by feed rate and depth of cut on cutting force component $\mathrm{F}_{\mathrm{y}}$.

5. The feed rate has greater static influence followed by depth of cut and spindle speed on cutting force component $\mathrm{F}_{\mathrm{z}}$.

6. The feed rate has greater static influence followed by spindle speed and depth of cut on surface roughness.

\section{REFERENCES}

[1] S.H. Park, Robust Design and Analysis for Quality Engineering, Chapman \& Hall, London, 1996.

[2] J.A. Ghani, I.A. Choudhury, H.H. Hassan, "Application of Taguchi method in the optimization of end milling parameter", Journal of Materials Processing Technology, Vol.145, 2004, pp. 84-92.

[3] J. Kopac, P. Krajnik, "Robust design of flank milling parameters based on grey-Taguchi method", Journal of Materials Processing Technology, Vol.191, 2007, pp. 400-403.

[4] T. Bendell, Taguchi methods, in: Proceedings of the 1988 European Conference on Taguchi Method, Elsevier, Amsterdam, 13-14 July, 1988.

[5] Julie Z. Zhang, Joseph C. Chen, E. Daniel Kirby, "Surface roughness optimization in an end-milling operationusing the Taguchi design method", Journal of Materials Processing Technology, Vol.184, 2007, pp. 233-239.

[6 ] E. Kuram, B. T. Simsek, B. Ozcelik, E. Demirbas, and S. Askin "Optimization of the Cutting Fluids and Parameters Using Taguchi and ANOVA in Milling" World Congress on Engineering, Vol II, 2010, pp. 978-988.

[7] W.H. Yang, Y.S. Tarng, Design optimisation of cutting parameters forturning operations based on the Taguchi method, J. Mater. Process. Technol. 84 (1998) 122-129

[8] T.R. Lin, Experimental design and performance analysis of tin-coated carbide tool in face milling stainless steel, J. Mater. Process. Technol. 5654 (2002) 1-7.

[9] K.L. Tsui, Modeling and analysis of dynamic robust design experiments, IEE Trans. 31 (1999) 113-1122.

[10] Zhang, H.P. Wang, Robust design of assembly and machining tolerance allocations, IEE Trans. 30 (1998) 17-29.

[11] Lou MS, Chen JC, Li MC, "Surface Roughness Prediction Technique for CNC End-Milling", J. Ind. Technology Vol.15, No.1, 1998, pp.1-6.

[12] Chen JC, Yang JL (2001), A Systematic Approach for Identifying Optimum Surface Roughness Performance in End-Milling Operations. J. Ind. Technol., 17 (2): 1-8.

[13] Mital, M. M., 1988. "Surface roughness prediction models for fine turning", Int. J. Prod. Res.26, pp. 1861-1876

[14] Mori T (1990), The New Experimental Design: Taguchi's Approach to Quality Engineering, ASI Press, Dearborn

[15] Lou MS, Chen JC, Li MC (1998). "Surface Roughness Prediction Technique For CNC End-Milling”, J. Ind. Technol., 15(1): 1-10

[16] D. M. Byrne and S. Taguchi. The Taguchi approach to parameter design. In Quality Congress Transaction - Anaheim, pages 168177. ASQC, May 1986 